\title{
SLC8 family of sodium/calcium exchangers (version 2019.4) in the IUPHAR/BPS Guide to Pharmacology Database
}

\author{
Jules Hancox ${ }^{1}$
}

1. University of Bristol, UK

\begin{abstract}
The sodium/calcium exchangers (NCX) use the extracellular sodium concentration to facilitate the extrusion of calcium out of the cell. Alongside the plasma membrane $\mathrm{Ca}^{2+}$-ATPase (PMCA) and sarcoplasmic/endoplasmic

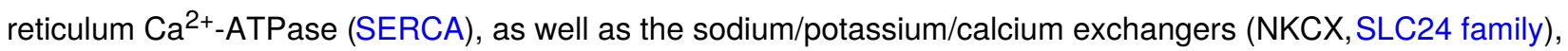
NCX allow recovery of intracellular calcium back to basal levels after cellular stimulation. When intracellular sodium ion levels rise, for example, following depolarisation, these transporters can operate in the reverse direction to allow calcium influx and sodium efflux, as an electrogenic mechanism. Structural modelling suggests the presence of 9 TM segments, with a large intracellular loop between the fifth and sixth TM segments.
\end{abstract}

\section{Contents}

This is a citation summary for SLC8 family of sodium/calcium exchangers in the Guide to Pharmacology database (GtoPdb). It exists purely as an adjunct to the database to facilitate the recognition of citations to and from the database by citation analyzers. Readers will almost certainly want to visit the relevant sections of the database which are given here under database links.

GtoPdb is an expert-driven guide to pharmacological targets and the substances that act on them. GtoPdb is a reference work which is most usefully represented as an on-line database. As in any publication this work should be appropriately cited, and the papers it cites should also be recognized. This document provides a citation for the relevant parts of the database, and also provides a reference list for the research cited by those parts.

Please note that the database version for the citations given in GtoPdb are to the most recent preceding version in which the family or its subfamilies and targets were substantially changed. The links below are to the current version. If you need to consult the cited version, rather than the most recent version, please contact the GtoPdb curators.

\section{Database links}

SLC8 family of sodium/calcium exchangers

http://www.guidetopharmacology.org/GRAC/FamilyDisplayForward?familyld=180

Transporters

NCX1(Sodium/calcium exchanger 1)

http://www.guidetopharmacology.org/GRAC/ObjectDisplayForward?objectld=945

NCX2(Sodium/calcium exchanger 2) 
http://www.guidetopharmacology.org/GRAC/ObjectDisplayForward?objectld=946

NCX3(Sodium/calcium exchanger 3)

http://www.guidetopharmacology.org/GRAC/ObjectDisplayForward?objectld=947

\section{References}

1. Dong H, Dunn J and Lytton J. (2002) Stoichiometry of the Cardiac $\mathrm{Na}+\mathrm{Ca} 2+$ exchanger NCX1.1 measured in transfected HEK cells. Biophys. J. 82: 1943-52 [PMID:11916852]

2. Iwamoto $\mathrm{T}$ and Kita S. (2006) YM-244769, a novel $\mathrm{Na}+/ \mathrm{Ca} 2+$ exchange inhibitor that preferentially inhibits NCX3, efficiently protects against hypoxia/reoxygenation-induced SH-SY5Y neuronal cell damage. Mol. Pharmacol. 70: 2075-83 [PMID:16973719]

3. Jost N, Nagy N, Corici C, Kohajda Z, Horváth A, Acsai K, Biliczki P, Levijoki J, Pollesello P and Koskelainen T et al.. (2013) ORM-10103, a novel specific inhibitor of the $\mathrm{Na}+/ \mathrm{Ca} 2+$ exchanger, decreases early and delayed afterdepolarizations in the canine heart. Br. J. Pharmacol. 170: 768-78 [PMID:23647096]

4. Secondo A, Pignataro G, Ambrosino P, Pannaccione A, Molinaro P, Boscia F, Cantile M, Cuomo O, Esposito A and Sisalli MJ et al.. (2015) Pharmacological characterization of the newly synthesized 5amino-N-butyl-2-(4-ethoxyphenoxy)-benzamide hydrochloride (BED) as a potent NCX3 inhibitor that worsens anoxic injury in cortical neurons, organotypic hippocampal cultures, and ischemic brain. ACS Chem Neurosci 6: 1361-70 [PMID:25942323]

5. Yamashita K, Watanabe Y, Kita S, Iwamoto T and Kimura J. (2016) Inhibitory effect of YM-244769, a novel $\mathrm{Na}^{+} / \mathrm{Ca}^{2+}$ exchanger inhibitor on $\mathrm{Na}^{+} / \mathrm{Ca}^{2+}$ exchange current in guinea pig cardiac ventricular myocytes. Naunyn Schmiedebergs Arch. Pharmacol. 389: 1205-1214 [PMID:27480939] 